\title{
Critical Analysis of the Government Schemes and its Impact With Specific Reference to Human Resources Issues in the Unorganized Sector in Rural Areas
}

\author{
Dr. Anup R. Ranade \\ Assistant Professor, Shri Ramdeobaba College of Engineering and Management, Nagpur \\ Email:ranadea@rknec.edu
}

Received: $20^{\text {th }}$ September 2018, Accepted: $11^{\text {th }}$ October 2018, Published: $31^{\text {st }}$ October 2018

\begin{abstract}
India although being a primarily agrarian economy, is still facing a lot of severe problems in its agricultural sector. In the present research paper a study has been done on the reasons for the distress in the agricultural sector. It was found that scarcity of labour and highly expensive labour force is the main reason for agriculture being no more viable activity at present. The reasons behind the existence of labour problem has been studied. It was found that this problem was not due to scarcity or shortage of labour in te market that the problem existed. The rural areas in the country are not sparsely populated and nearly $65 \%$ of the Indian population lives in villages.

The labour shortage had occurred because of implementation of two schemes by the Government of India in rural areas. The MGNREGA and the Antodaya Anna Yojana being implemented by the administration compositely results in a situation where potential labourers are unwilling to work beyond a certain limit and this limit is too little to suffice the demand for labour in the farm sector.
\end{abstract}

Keywords

MGNREGA, Antoday Anna Yojana, Government Schemes, Subsidies, Labour Shortage, Agriculture

\section{Introduction}

India has been primarily an agrarian economy. Of lately the tertiary sector i.e. the service sector has shown exponential growth and hence has contributed greatly to the reduction in the levels of unemployment [1]. It has surpassed the secondary sector or the Industrial sector in terms of generating employment long ago. It has even surpassed the production sector in its share in GDP [2]. India has witnessed a technological revolution in recent years, which has resulted in India becoming a very attractive market for various service providers.

\author{
Share in GDP : $\quad$ Agriculture - 17.5\%, Industry - 20\%, Service - 62.5\% \\ Employment Generation : Agriculture - 52\%, Industry - 14\%, Service - 34\% \\ (Economy of India, 2012)
}

In spite of these facts, Agriculture still remains the major employer of the population and has a significant contribution in the GDP. This is thanks to the fertile soil, numerous rivers, conducive warm weather and the unique phenomenon of monsoon winds that India is blessed with. These factors have helped India sail through smoothly the difficult times of draught, epidemics, natural disasters and wars.[3] It has led India from being an economy of scarcity to an economy of self sufficiency. It is now leading India towards an economy of abundance.

Taking a cue from the growth stories of the developed world, economists worldwide were of the opinion that any country passes through three stages of development, wherein firstly the primary sector is dominant, then the secondary sector develops and overtakes the primary sector in the share in GDP. The secondary sector becomes dominant and the primary sector gets marginalized. In the further course of development, the tertiary sector starts developing, overtakes primary \& secondary sectors in its share in GDP and slowly becomes dominant in the economy with the share of primary sector in GDP getting reduced to basic minimum.[4]

However, India was a different story. Here the secondary sector did never rise to prominence. As the agricultural sector slowly reduced in its share in GDP, directly the tertiary or service sector developed exponentially, acquiring the major share in GDP and employing a huge number of people. In the whole scenario the tertiary sector got extreme care and nurturing by the Government. [5] The Government could not visualize or could not accept the fact that Agriculture could still play a very important role in the economy despite the economy reaching the developed stage. The result was that the Agriculture sector was neglected all through these years after independence. Whatever steps that were taken by the Government for Agricultural sector were all curative or relief measures and were not innovative and futuristic.[6] 
As a result of all these, the growth rate of the agricultural sector has been disappointing and most of the middle scale and small scale farmers have been in utter distress. The brighter minds in younger generations of these class of farmers do not find agriculture as a viable option and move on towards the larger cities for better job opportunities. Those who remain in agricultural business neither have the capability, motivation and knowledge nor any incentive to try to progress in their agricultural business. [7]

On the other hand, the large scale farmers are also disappointed by the ROI in their fields and hence use their farm debts for their other industrial or retail businesses.[8]

As an aggregate, there is an absence of capital, knowledge, technology and talent in the present day agricultural sector of India, despite it having huge potential.

This distress has cost India immensely, with thousands of farmers having committed suicides due to crop failures. [9]

This phenomenon has become common in India, though it may seem shocking and unbelievable for any non-Indian.

\section{Research Problem}

This research, is an attempt to study the impact of various Government Schemes and its impact with specific reference to Human Resources issues in the unorganized sector in rural areas of Nagpur District.

\section{Materials \& Methods}

\section{Complex Business Environment for the Farmer and the Risks Involved.}

The investments required in the farming activity by the farmers are land, tractor and other machinery for tilling etc.

The costs to be incurred are for labour, seeds, fertilizers, pesticides, insecticides, protective fencing etc.[10]

The operations involved are tilling, sowing, treating, cutting, sorting, cleaning etc. On completion of these operations, the farmer has to transport his product to the wholesale market and sell it in an open auction. During the whole activity, a farmer has to face numerous problems which can be treated as risks.

The Indian farmer does his business of production and sale of agricultural product under numerous constraints, risks and complex situations. Under these conditions, recovering the amount invested in the activity, earning for yearly expenses of the family and making a profit becomes difficult.[11]

To add to the woes, behavioral impact of family members, peers, fellow villagers, subordinate laborers, Gram Panchayat, Bank and others Government Officers and their apathy, generally are unfavorable mainly for small, marginal and medium sized farmers.[12]

\section{Research Methodology \\ Sampling \& Data Collection}

The universe of this group of farmers consists of infinite population. Samples were drawn for study from this population by using stratified sampling in the complex random sampling design. Each Taluqa of Nagpur District viz., Nagpur Rural, Umred, Kalmeshwar, Saoner, Narkhed, Katol, Hingna, Bhiwapur, Kamthi, Kuhi, Maouda, Ramtek and Parshivani were considered to be strata and samples were drawn randomly from each strata. These samples who were farmers from each taluqa were from different families of that particular taluqa. Thus a total of about 155 farmers were studied under this research.

These farmers were asked questions relating to their incomes, various expenses on agriculture and household and their savings, problems faced by them in agriculture, and about their dependents.

Such a sampling ensured that each taluqa of Nagpur District is being equally represented and a fair view of the overall Nagpur District is obtained at the end of the study.

\section{Sample Generalisability}

The using of stratified sampling for the Study Group ensures that the samples or respondents taken are from all the Taluqas of Nagpur District. Thus each and every taluqa is represented in the samples. The study on farmers of such each taluqa gave a fair idea about the trends prevalent across that taluqa. Thus the trends of each taluqa were fairly represented in the tend of 10 farmers in each taluqa. When all these trends from all the 14 taluqas were combined and analysed and interpreted, the resulting conclusion was found to be fairly true about Nagpur District as a whole. Thus the results obtained from the study of samples under consideration would be perfectly generalisable across the whole of Nagpur and was fairly applicable to all the farmers of the Nagpur District.

\section{Data Analysis and Interpretation:}

When data collected by way of questionnaires was analyzed following observations were made; 


\section{Difficulties Faced by Farmers in their Operations}

\begin{tabular}{|l|c|c|}
\hline Problems & No of Farmers & Percentage \\
\hline Many Problems including all & 41 & $26 \%$ \\
\hline Labour Scarcity & 85 & $55 \%$ \\
\hline Water Scarcity & 51 & $33 \%$ \\
\hline Inflation & 39 & $25 \%$ \\
\hline Uneven Rainfall & 28 & $18 \%$ \\
\hline Lack of funds & 19 & $12 \%$ \\
\hline Crop Failure & 17 & $11 \%$ \\
\hline Lack of Fertilizers & 9 & $6 \%$ \\
\hline Unfair Market Price & 9 & $6 \%$ \\
\hline Corruption & 9 & $6 \%$ \\
\hline Damage by pest & 8 & $5 \%$ \\
\hline lack of seeds & 6 & $4 \%$ \\
\hline Lack of facilities & 4 & $3 \%$ \\
\hline Damage by animals & 3 & $2 \%$ \\
\hline Low productivity & 3 & $2 \%$ \\
\hline Lack of Pestisides & 2 & $1 \%$ \\
\hline Pollution & 2 & $1 \%$ \\
\hline Lack of Knowledge & 2 & $1 \%$ \\
\hline Faulty Govt Schemes & 1 & $1 \%$ \\
\hline Lack of aspiration & 1 & $1 \%$ \\
\hline lack of Hard work & 1 & $1 \%$ \\
\hline
\end{tabular}

Table 1: Problems Faced during Farming

It was found as seen in Table No.1 and the adjoining graph, that, the most common problem out of all the problems faced by the farmers was that of labour. In all, there were 20 problems that were identified from the survey as named by the different farmers. Out of those 20 problems, $55 \%$ of the farmers mentioned about labour scarcity or costly labour. Nearly 85 farmers out of 155 were of this opinion. There was a time when India was known for cheap labour. The unskilled labour in India was cheap and ample.

On one hand, most farmers say that finding a labour at affordable cost is the biggest difficulty. NREGA and Antoday have complicated the matter. On the other hand, many farmers are finding a support for family expenses, through working as labor on the fields of other farmers.

\section{Results \& Discussion}

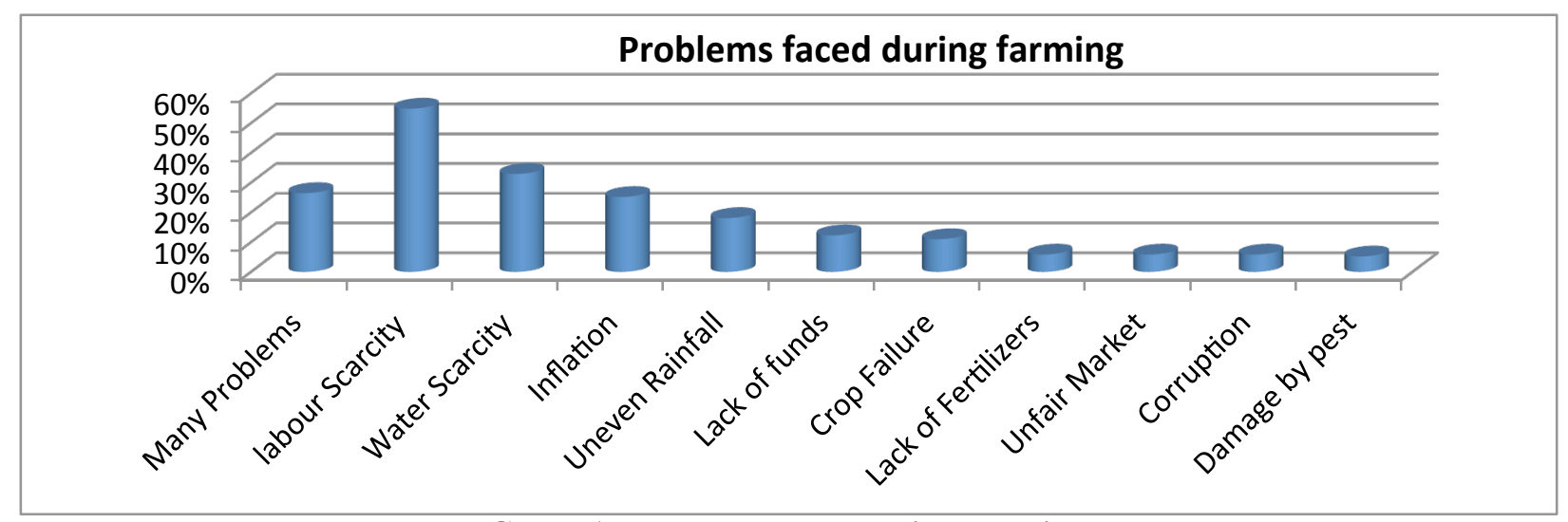

Graph 1: Problems Faced during Farming

In rural India today, especially for the agriculture sector, unskilled labour is scanty and is highly expensive. This is a serious and humongous problem, that has dealt a heavy blow to the agricultural sector. 
There are two Distinct Government schemes that have been implemented in rural areas of India.

The MGNREGA was initiated with the objective of "enhancing livelihood security in rural areas by providing at least 100 days of guaranteed wage employment in a financial year, to every household whose adult members volunteer to do unskilled manual work". Another aim of MGNREGA is to create durable assets (such as roads, canals, ponds and wells). Employment is to be provided within $5 \mathrm{~km}$ of an applicant's residence, and minimum wages are to be paid. If work is not provided within 15 days of applying, applicants are entitled to an unemployment allowance. Thus, employment under MGNREGA is a legal entitlement.

MGNREGA is to be implemented mainly by Gram Panchayats. The involvement of contractors is banned. Labourintensive tasks like creating infrastructure for water harvesting, drought relief and flood control are also undertaken. Under MGNREGA, the rural labour has been guaranteed Rs 160/- to Rs.280/- per day of employment (differing in different states) and hence, the labour charges, which was about Rs.30/- per day once, has become 5 times higher. This has totally changed the dynamics of expenditure patterns in agriculture.[13]

\section{Antodaya Anna Yojana}

This situation is compounded by Antoday Anna Yojana scheme, wherein the poor population get food for Rs.2/or Rs.3/- per kg.

After identifying the "poorest of the poor" (the 10,000,000 poorest families in the Below Poverty Line category) through extensive surveying, the government began providing them an opportunity to purchase up to 37 kilograms of rice and wheat at a highly subsidised cost of Rs.3/- per KG of rice and Rs.2/- per kg of wheat. Poor families were identified by their respective state rural development facilities through use of surveys. The scheme has been expanded twice, once in June 2003 and then in August 2004, adding an additional 5,000,000 BPL families each time and bringing the total number of families covered up to 20,000,000.[14]

Due to availability of food for such a low cost, the laborers are able to earn money, enough to feed their families, by working just few days in a month. There is no more motivation or reason for them to work for all days in a month. Most of them work only few days in a month, and remain idle in rest of the days and easily feed their families rather than toiling hard for the whole month and earning extra money.

The Indian farmers today are highly dependant on laborers, for their various activities that form part of their yearly operations.

Labour is required for cleaning of farm, ploughing, sowing, spraying fertilizers, pesticides, guarding farms, removing weeds and rotten or damaged crops, cutting crops when ready, transporting, cleaning and packaging and selling the product to the dealers.

Each of the above activity is required to be done at exactly specific point of time, and within a limited short period of time. Any delay or slowing down of the work may result in complete loss of all the products. The situation becomes even more complex due to the fact that this specific point of time and the period of the work is same for all the farms, at least for a particular region.

Due to this, there is a demand for labour by all the farmers at the same time and for the same period. This sudden spurt of demand of labour at particular periods of the year, coupled with already scarce and expensive labour, either raises the expenditure of the farmers hugely, making the whole operation cost ineffective or damages the investments done till that point of time due to unavailability of labour at a particular time.

The use of machinery could be seen as a solution to the problem. However use of machinery in farming by Indian farmers is very limited and on a low scale. The reasons for this are, unavailability of machines in local market, high cost of machines, unavailability or scarcity of electric power or diesel required to run the machines, traditional mindset of working without machines and awareness about ill effects of use of machines.

\section{Conclusion}

The NREGA and Antoday Anna Yojana are good initiatives taken by the Government to improve the condition of the poor labourers. However, this unforeseen conflict of interests has arisen, which has hampered operations of crores of farmers of India, and is possibly going to cause severe damage to profitability in the agricultural sector, pushing more and more farmers towards debt and losses. Hence it is suggested that NREGA and Antoday Anna Yojana be made conditional, with the condition that, the beneficiary of these schemes must have worked for certain minimum number of hours per month, say 5 hours $\times 5$ days $\times 4$ weeks $=100$ hours,

in order to be eligible for the scheme. Such a condition would encourage all the labourers to work for more hours, thus solving the problem of labour scarcity. Any step taken, to solve the problem may have its own drawbacks and may lead to its own ill effects. This however does not mean that we stop taking steps. Its important to identify 
timely, the ill effects and take corrective measures to control the damage. A system slowly evolves through this exercise, over a period of time. The problems get slowly minimized as a result of continued efforts and steps taken. Farming is a crucial activity in a traditionally agrarian economy like India. Although today Indian economy is making huge strides in the field of technology, manufacturing, and services industry, still in a well populated nation like India, agriculture has an important role to perform in maintaining balance and stability in the economy. A chronic shortage of an important factor of production like labour in the rural economy is already having a very detrimental effect on it. The fact that the problem exists in a highly populated country is in itself very surprising.

The reason for development of such a problem of scarcity in abundance is due to the combined effect of the two Government Schemes MNREGA and Antoday Anna Yojana. Both the schemes need a few tweaks $\backslash$ in order to fix this chronic problem of scarcity of labour.

\section{References}

1. Dewett, K., Varma, J., \& Sharma, M., 2001, $44^{\text {th }}$ ed. Indian Economics, S.Chand \& Company Ltd., New Delhi.

2. Datt, R. \& Sundharam, K.P.M., 2006, $54^{\text {th }}$ ed. Indian Economy, S.Chand \& Company Ltd., New Delhi.

3. Gupta, Kulwant Rai, "Issues in Indian agriculture", Atlantic Publishers \& Distributors, 1980

4. Gupta, S.B., 2003, $12^{\text {th }}$ ed.., Monetary Economics, Institutions, Theory \& Policy, S.Chand \& Company Ltd., New Delhi.

5. Joshi, S., 1995, Macroeconomic Policies, Issues \& Evidence, Anmol Publications Pvt. Ltd., New Delhi.

6. Desai, V., 2009, $3^{\text {rd }}$ ed., The Indian Financial System \& Development, Himalaya Publishing Pvt. Ltd., Mumbai.

7. Gupta, S.P., $2005,22^{\text {nd }}$ ed., Modern Economic Theory, S.Chand \& Company Ltd., New Delhi.

8. Dewett, K., 2005, $22^{\text {nd }}$ ed., Modern Economic Theory, S.Chand \& Company Ltd., New Delhi.

9. Karmarkar, K.G., 2008, Microfinance in India, Sage Publications India Pvt. Ltd., New Delhi.

10. AGRICOOP, Maharashtra Government <http://agricoop.nic.in/Agriculture \%20Contingency\%20Plan/Maharastra/MH18-\%20Nagpur.pdf>

11. Agricultural Facts on Nagpur, Maharashtra Government $<$ http://nagpur. gov.in/htmldocs/agri.htm $>$

12. MGNREGA, <nrega.nic.in/netnrega/home.aspx >

13. Antyoday Anna Yojana, $<$ http://data.gov.in/keywords.antyodaya-anna-yojana $>$ 